\title{
Dual effects of arsenic trioxide on tumor cells and the potential underlying mechanisms
}

\author{
XIAO ZHANG ${ }^{1}$, DAHAI YU ${ }^{1}$, HUAIZE GENG ${ }^{1}$, FENGMEI LI ${ }^{1}$, LIN LV $^{1}$, \\ LEI ZHAO ${ }^{1}$, CAICHUAN YAN ${ }^{1}$ and BAOXIN LI ${ }^{1,2}$ \\ ${ }^{1}$ Department of Pharmacology, College of Pharmacy; ${ }^{2}$ The State-Province Key Laboratory of Biopharmaceutical Engineering, \\ Harbin Medical University, Harbin, Heilongjiang 150086, P.R. China
}

Received September 29, 2017; Accepted June 14, 2018

DOI: $10.3892 / \mathrm{ol} .2018 .9086$

\begin{abstract}
The human ether-a-go-go related gene (hERG) encodes the rapid delayed rectifier $\mathrm{K}^{+}$channel. hERG not only serves an important role in heart muscle and cardiomyocyte excitability by regulating action potential repolarization, but also represents a selective advantage for cancer cell proliferation. Arsenic trioxide is a traditional Chinese medicine, which has been previously identified as an efficient tumor suppressor, particularly in the treatment of acute pro-myelocytic leukemia. However, studies have also reported that long-term exposure to arsenicals may lead to the formation of malignant tumors. In the present study, the effect of low-dose arsenic trioxide on the proliferation and apoptosis of tumor cells was investigated, as were the potential underlying mechanisms of this effect. The data demonstrated that low-dose arsenic trioxide $(0.1 \mu \mathrm{M})$ enhanced the viability and apoptosis of tumor cells expressing hERG channels following long-term incubation. However, in tumor cells lacking hERG channels, low-dose arsenic trioxide had no effect. Therefore, we hypothesized that this hormesis effect of low-dose arsenic trioxide on tumor cells may be associated with the hERG channel. Furthermore, low dose arsenic trioxide promoted the hERG-channel current by changing the kinetics of channel gating and prolonging the open-channel stage. Simultaneously, high-dose $\mathrm{As}_{2} \mathrm{O}_{3}$ (1 or $10 \mu \mathrm{M}$ ) significantly reduced the expression of hERG in tumor cells compared with the control group, which resulted in reduced proliferation rate and promotion of apoptotic rate. The results of the present study demonstrate that the dual effects of arsenic trioxide on hERG channels vary according to concentration, resulting in the dual effects on tumor cells. This
\end{abstract}

Correspondence to: Professor Baoxin Li or Dr Caichuan Yan, Department of Pharmacology, College of Pharmacy, Harbin Medical University, 157 Baojian Road, Harbin, Heilongjiang 150086, P.R. China

E-mail: libx64@hotmail.com

E-mail: yancaichuan@hrbmu.edu.cn

Key words: human ether-a-go-go related gene, arsenic trioxide, proliferation, apoptosis, tumorigenesis provides a theoretical basis for the potential clinical application of arsenic trioxide, suggesting that hERG channels are an important target in preventing and treating tumorigenesis during arsenicosis.

\section{Introduction}

The human ether-a-go-go-related gene (hERG) encodes the pore-forming subunits of the rapid delayed rectifier potassium channel (1). Studies have reported that a wide variety of therapeutic compounds could induce acquired long QT syndrome (acLQTS) by inhibiting hERG channels, including antiarrhythmic drugs and antitumor agents (2-4). By contrast, the association between the enhanced activation of hERG channels and tumorigenesis remain unclear. Therefore, it is essential to examine novel compounds or therapies for restoring the physiological state of ion channel balance.

Arsenic trioxide $\left(\mathrm{As}_{2} \mathrm{O}_{3}\right)$, a traditional Chinese medicine, is an effective treatment for acute pro-myelocytic leukemia (APL) $(5,6)$. Previous studies have demonstrated that $\mathrm{As}_{2} \mathrm{O}_{3}$ has an inhibitory effect on the proliferation of various types of cancer, including APL, gastric carcinoma and breast cancer $(7,8)$. On the other hand, the carcinogenic effects of $\mathrm{As}_{2} \mathrm{O}_{3}$ have been concurrently reported. It has been demonstrated that low-dose $\mathrm{As}_{2} \mathrm{O}_{3}$ can promote the occurrence and development of tumors (9-11). However, the underlying mechanism of this effect remains unclear. In addition, increasing evidence has indicated that plasma membrane hERG channels are aberrantly expressed in various types of cancer and serve essential roles in numerous crucial cellular events $(12,13)$. Inhibition of the hERG channel has indicated a significant therapeutic effect in various types of tumors $(12,14)$. Based on previous findings that $\mathrm{As}_{2} \mathrm{O}_{3}$ could regulate the protein expression level of hERG through multiple signal pathways (15), we hypothesize that a low dose of $\mathrm{As}_{2} \mathrm{O}_{3}$ exerts ahormesis effect by affecting the expression and/or function of hERG channels.

In the present study, the possible role of hERG in tumor progression was investigated when tumor cells were exposed to low-dose $\mathrm{As}_{2} \mathrm{O}_{3}(0.1 \mu \mathrm{M})$. Notably, the data demonstrate that a low dose of $\mathrm{As}_{2} \mathrm{O}_{3}$ has a hormesis effect on tumor cells, possibly due to the involvement of hERG channels. To the best of our knowledge, we are the first to hypothesize that the hERG channel participates in the dual effects of $\mathrm{As}_{2} \mathrm{O}_{3}$ in tumor cells. 
Prior to this, $\mathrm{As}_{2} \mathrm{O}_{3}$ was considered to be an hERG channel inhibitor $(15,16)$ and that a low dose of $\mathrm{As}_{2} \mathrm{O}_{3}$, compared with a high dose of $\mathrm{As}_{2} \mathrm{O}_{3}$, could exert an inverse effect. Furthermore, $\mathrm{As}_{2} \mathrm{O}_{3}$ has been demonstrated to have a dual effect on hERG channels according to different concentrations, providing a theoretical basis for the potential clinical use of $\mathrm{As}_{2} \mathrm{O}_{3}$. Further research examining the crucial dosages $\mathrm{As}_{2} \mathrm{O}_{3}$ for apoptosis and hormesis processes is required.

\section{Materials and methods}

Cell culture. The following cell lines were purchased from Chinese Peking Union Medical College (Peking, China): 293 cells that stably expressed the wild-type hERG gene (hERG-293), the breast cancer cell line, MCF-7, and the lung cancer cell line A549. hERG-293 cells were cultured in DMEM medium containing $10 \%(\mathrm{v} / \mathrm{v})$ fetal bovine serum (FBS; Gibco; Thermo Fisher Scientific, Inc., Waltham, MA, USA) and $400 \mathrm{mg} / \mathrm{ml}$ of geneticin (G-418; Invitrogen; Thermo Fisher Scientific, Inc.). MCF-7 cells and A549 cells were grown in DMEM and Kaighn's Modification of Ham's F-12 (F-12K) medium (both Gibco; Thermo Fisher Scientific, Inc.) respectively, with $10 \%(\mathrm{v} / \mathrm{v}) \mathrm{FBS}$. All cells were cultured at $37^{\circ} \mathrm{C}$ in $5 \% \mathrm{CO}_{2}$. The present study was approved by the Ethical Committee of the Harbin Medical University (Heilongjiang, China).

Whole cell patch-clamp recordings. hERG currents were recorded in the whole cell voltage-clamp (VC) mode, and action potential durations (APDs) were recorded in the current-clamp mode with an Axopatch 200B amplifier (Molecular Devices, LLC, Sunnyvale, CA, USA) in hERG-HEK293 cells. Heat-polished patch pipettes had tip resistances of 1-3 M $\Omega$ when filled with the internal pipette solution. The pipette solution for hERG current recording contained $130 \mathrm{mM}$ $\mathrm{KCl}, 1 \mathrm{mM} \mathrm{MgCl}{ }_{2} \cdot 6 \mathrm{H}_{2} \mathrm{O}, 10 \mathrm{mM}$ HEPES, $5 \mathrm{mM} \mathrm{Mg}$-ATP, $5 \mathrm{mM}$ EGTA, and $0.1 \mathrm{mM}$ GTP (pH 7.3 with $\mathrm{KOH}$ ). The extracellular solution contained $136 \mathrm{mM} \mathrm{NaCl}, 5.4 \mathrm{mM} \mathrm{KCl}$, $5 \mathrm{mM}$ HEPES, $1 \mathrm{mM} \mathrm{MgCl} \cdot 6 \mathrm{H}_{2} \mathrm{O}, 1 \mathrm{mM} \mathrm{CaCl}_{2}$ and $10 \mathrm{mM}$ glucose (pH 7.4 with $\mathrm{NaOH}$ ). hERG currents were evoked through a 4-sec repolarizing step to $-50 \mathrm{mV}$ and followed by a 2-sec depolarization step with a $10 \mathrm{mV}$ stepwise increase from -60 to $40 \mathrm{mV}$, with the primary holding potential being $-80 \mathrm{mV}$. For the activation curves of hERG channels, cells were evoked through a 2.5 -sec repolarizing step to an $+40 \mathrm{mV}$ inactivation step, following a $10 \mathrm{mV}$ stepwise increase from -120 to $+20 \mathrm{mV}$, while the onset of inactivation curves was recorded with a $10 \mathrm{mV}$ stepwise increase from -120 to $+30 \mathrm{mV}$. The time interval of onset of inactivation was investigated by fitting a single exponential function to current traces in the third pulse of the protocol. The recovery of hERG channels from inactivation curves was recorded with a $10 \mathrm{mV}$ stepwise increase from -120 to $+30 \mathrm{mV}$. The time constant of recovery from inactivation was calculated by fitting a single exponential function to the peak of tail current traces between -60 and $-30 \mathrm{mV}$. Experiments were recorded and analyzed on one cell per recording. Currents were fitted to a Boltzmann function using Clampfit 9.2 (Axon Instruments; Molecular Devices, LLC, Sunnyvale, CA, USA), where $V_{1 / 2}$ is the half-maximum activation voltage.
Western blot analysis. The protein expression level of hERG was monitored using western blot analysis. $\mathrm{As}_{2} \mathrm{O}_{3}$ was diluted $(0.1,1$ and $10 \mu \mathrm{M})$ and added to $1 \times 10^{6}$ hERG-293 cells for $24 \mathrm{~h}$ at $37^{\circ} \mathrm{C}$ prior to analysis by western blotting. The cells were washed using ice-cold PBS. Subsequently, protein was harvested with radio immunoprecipitation assay buffer containing $1 \%$ protease inhibitor (Sigma-Aldrich; Merck KGaA, Darmstadt, Germany). Protein concentration was assessed using the bicinchoninic acid assay (Beyotime Institute of Biotechnology, Haimen, China). A total of $150 \mu \mathrm{g}$ protein was loaded per lane and separated using $8 \%$ SDS-PAGE. Proteins were then transferred to nitrocellulose membranes (Agilent Technologies, Inc., Santa Clara, CA, USA) and incubated with $5 \%$ non-fat milk (BD Biosciences, Franklin Lakes, NJ or San Jose, CA, USA) for $2 \mathrm{~h}$ at room temperature. The membranes were subsequently incubated with primary antibodies against hERG (dilution, 1:1,000; cat. no., sc-20130; Santa Cruz Biotechnology, Inc., Dallas, TX, USA) and $\beta$-actin (dilution, 1:500; cat. no., TA-09; Beijing Zhongshan Jinqiao Biotechnology Co., Ltd., Beijing, China) overnight at $4^{\circ} \mathrm{C}$ with agitation. The membranes were washed with $0.05 \%$ Tris-buffered saline (TBST) three times and incubated with IRDye 800CW-labelled, goat anti-rabbit IgG secondary antibodies (1:8,000; cat. no. 926-32211; Li-Cor Inc., Lincoln, NE, USA) for $1 \mathrm{~h}$ in the dark at room temperature. Subsequent to being washed three times with $0.05 \%$ TBST, bands were detected and analyzed with the Odyssey CLx Infrared imaging system (LI-COR Biosciences, Lincoln, NE, USA). To quantify the western blotting data, the intensities of proteins of interest in each gel were firstly normalized to their respective actin intensities, then the normalized intensities were compared with the intensity of the control group and expressed as relative values to their controls.

MTT assay. Proliferation was assessed using an MTT assay. Briefly, $5 \times 10^{3}$ cells were treated with various concentrations $(0.1,1$ and $10 \mu \mathrm{M})$ of $\mathrm{As}_{2} \mathrm{O}_{3}$ for 24 and $72 \mathrm{~h}$. Next, a mixture of $180 \mu \mathrm{l}$ culture medium and $20 \mu \mathrm{l}$ MTT reagent (Sigma-Aldrich; Merck KGaA) was added to each well. Subsequently, $100 \mu 1$ DMSO was added to each well and mixed to solubilize the colored crystals. The absorbance was measured at $490 \mathrm{~nm}$ after $4 \mathrm{~h}$ of incubation at $37^{\circ} \mathrm{C}$.

Flow cytometry (FCM) analysis of apoptosis. Quantitative assessment of apoptosis was conducted using an Annexin V Assay kit (Beyotime Institute of Biotechnology). Cells were centrifuged at $1,000 \mathrm{x}$ g for $5 \mathrm{~min}$ at $4^{\circ} \mathrm{C}$ following trypsinization, then washed with ice-cold PBS twice. The pellet was resuspended in the ice-cold binding buffer provided with the kit. Subsequently, $10 \mu \mathrm{l}$ Annexin V-FITC and $5 \mu \mathrm{l}$ propidium iodide (PI) were added to the cell suspension, which was maintained on ice in the dark for $15 \mathrm{~min}$. The samples were then assessed for viable (Annexin $\mathrm{V}^{-} / \mathrm{PI}^{-}$), early apoptotic (Annexin $\mathrm{V}^{+} / \mathrm{PI}^{-}$), late apoptotic $\left(\right.$Annexin $\mathrm{V}^{+} / \mathrm{PI}^{+}$) and necrotic (Annexin $\mathrm{V}^{-} / \mathrm{PI}^{+}$) cells using a flow cytometer (Fc500MDL) and analyzed by CXP Analysis Software (version 2.0) (both Beckman Coulter, Inc., Brea, CA, USA).

Statistical analysis. Data are presented as the mean \pm standard error of the mean. The Student's t-test was used for 
A

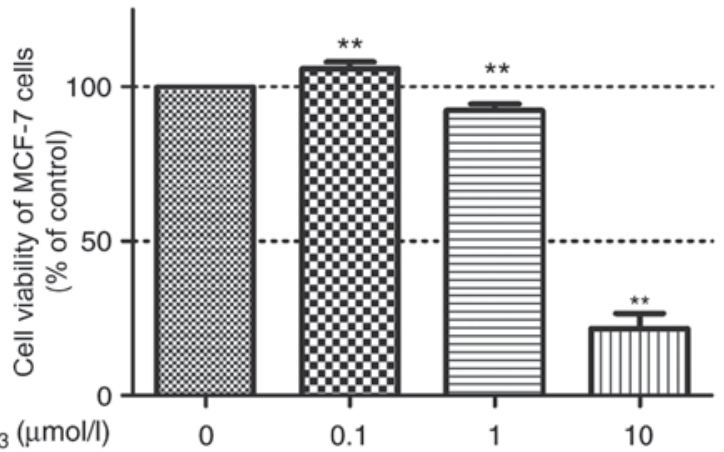

C

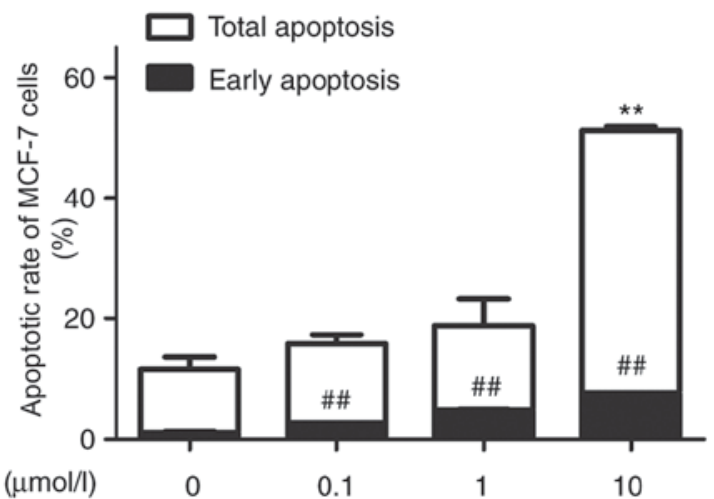

B

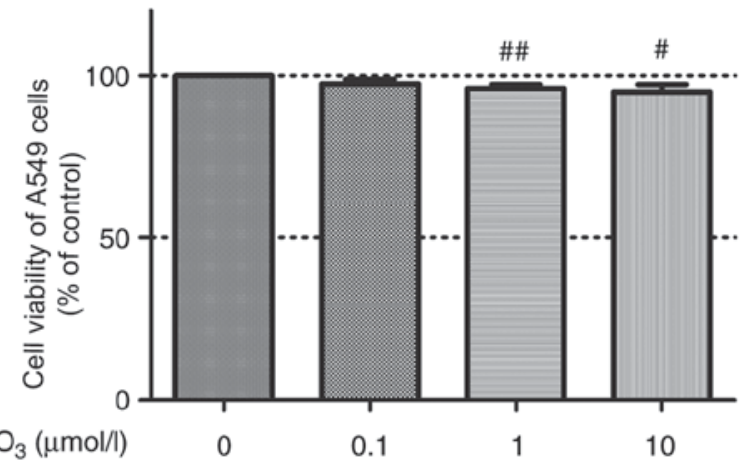

D

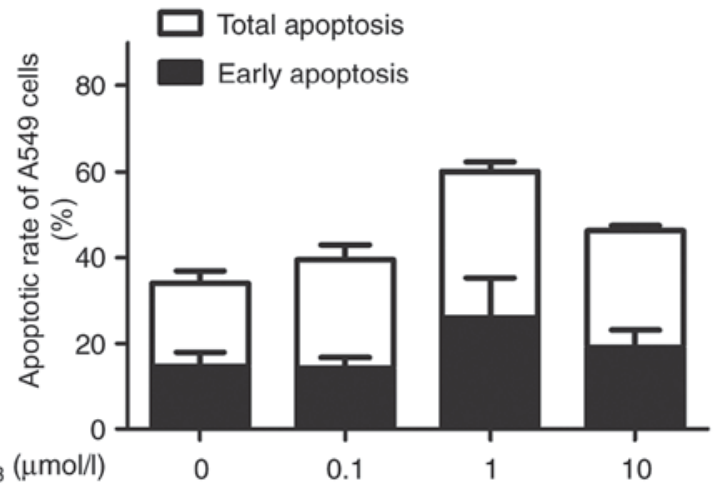

Figure 1. Cell viability and apoptotic rate of MCF-7 and A549 cells was examined with $0,0.1,1$ and $10 \mu \mathrm{M} \mathrm{As} \mathrm{O}_{3}$ treatment. (A) Viability of MCF-7 cells was determined by MTT assay. (B) Viability of A549 cells was determined by MTT assay. (C) Apoptotic rate of MCF-7 cells was determined by flow cytometry. (D) Apoptotic rate of A549 cells was determined by flow cytometry. Data are presented as the mean \pm standard deviation ( $\mathrm{n}=3$ ). ${ }^{\#} \mathrm{P}<0.05$ vs. $0 \mu \mathrm{M} \mathrm{As}_{2} \mathrm{O}_{3}$, ${ }^{* *} \mathrm{P}<0.01$ vs. $0 \mu \mathrm{M}$ total apoptosis or, ${ }^{\# \#} \mathrm{P}<0.01$ vs. $0 \mu \mathrm{M}$ early apoptosis. $\mathrm{As}_{2} \mathrm{O}_{3}$, arsenic trioxide.

comparisons between two groups, and analysis of variance was used for the comparison of multiple groups with the Student-Newman-Keuls post hoc test. $\mathrm{P}<0.05$ (two-tailed) was considered to indicate a statistically significant difference. GraphPad Prism 5.0 software was used for statistical analysis (GraphPad Software, Inc., La Jolla, CA, USA).

\section{Results}

Effects of hormesis on tumor cells induced by $\mathrm{As}_{2} \mathrm{O}_{3}$. The viability in response to $\mathrm{As}_{2} \mathrm{O}_{3}$ stimulation was compared in two types of cancer cells: MCF-7 and A549 cells. In our previous screening experiments, it was indicated that MCF-7 cells overexpressed hERG channels, whereas A549 cells rarely expressed hERG channels. In contrast with the A549 cells, the MCF-7 cells expressed endogenous hERG channels (17). An MTT assay was performed to assess viability following treating the cells with $0.1,1$ and $10 \mu \mathrm{M}$ of $\mathrm{As}_{2} \mathrm{O}_{3}$ for $72 \mathrm{~h}$ (Fig. 1A). Application of 1 or $10 \mu \mathrm{M} \mathrm{As}_{2} \mathrm{O}_{3}$ produced a suppressive effect on MCF-7 cell proliferation, resulting in a 7.69 and $78.30 \%$ reduction in MCF-7 cell viability at 1 and $10 \mu \mathrm{M}$, respectively. Notably, a dual effect of $\mathrm{As}_{2} \mathrm{O}_{3}$ was observed, since MCF-7 cell viability increased by $\sim 6 \%$ in the $0.1 \mu \mathrm{M} \mathrm{As} \mathrm{O}_{3}$ group compared with the control group. However, a low concentration $(0.1 \mu \mathrm{M})$ of $\mathrm{As}_{2} \mathrm{O}_{3}$ did not express the hormesis effect on the proliferation of A549 cells. A high dose of $\mathrm{As}_{2} \mathrm{O}_{3}(1$ and $10 \mu \mathrm{M})$ reduced the viability of $\mathrm{A} 549$ cells in a concentration-dependent manner, while $0.1 \mu \mathrm{M} \mathrm{As}_{2} \mathrm{O}_{3}$ did not significantly affect A549 proliferation compared with the control group (Fig. 1B).
Considering that numerous antitumor drugs suppress proliferation and simultaneously promote apoptosis, a quantification of $\mathrm{As}_{2} \mathrm{O}_{3}$-induced apoptotic cells was conducted via flow cytometry with Annexin V/PI analysis. MCF-7 cells and A549 cells were treated with $0.1,1$ and $10 \mu \mathrm{M}$ of $\mathrm{As}_{2} \mathrm{O}_{3}$ for $72 \mathrm{~h} . \mathrm{As}_{2} \mathrm{O}_{3}$ treatment resulted in a dose-dependent increase in apoptotic rate in MCF-7 cells compared with control (Fig. 1C). Subsequent to treatment with $0.1,1$ and $10 \mu \mathrm{M} \mathrm{As}{ }_{2} \mathrm{O}_{3}$ for $72 \mathrm{~h}$, apoptotic rate of 15.9, 18.8 and $51.1 \%$ in MCF-7 cells were observed, respectively. However, $\mathrm{As}_{2} \mathrm{O}_{3}$ did not indicate significant cytotoxic effects in A549 cells (Fig. 1D; P>0.05).

In the apoptosis experiments, all cells were cultured without FBS for $72 \mathrm{~h}$, therefore only apoptosis occurred. However, in the proliferation experiments, all the cells were cultured with FBS for $72 \mathrm{~h}$, resulting in proliferation and apoptosis. Therefore, the data primarily demonstrated that a low dose of $\mathrm{As}_{2} \mathrm{O}_{3}$ could stimulate $\mathrm{MCF}-7$ proliferation, whereas no significant effect on A549 cells was exhibited.

Dual effects of $\mathrm{As}_{2} \mathrm{O}_{3}$ on the expression of hERG channels. In our previous study, it was demonstrated that $3 \mu \mathrm{M} \mathrm{As}_{2} \mathrm{O}_{3}$ could damage the hERG current and downregulate the expression of hERG channels by disturbing the trafficking process of hERG protein to the cellular membrane (18). However, the effect of low-dose $\mathrm{As}_{2} \mathrm{O}_{3}$ on hERG channels requires further investigation. Therefore, in the present study, western blot analysis was used to identify the effect of low-dose $\mathrm{As}_{2} \mathrm{O}_{3}$ on the protein expression level of hERG. Following incubation with low-dose $\mathrm{As}_{2} \mathrm{O}_{3}(0.1,0.5$ and $1 \mu \mathrm{M})$ for $24 \mathrm{~h}, \mathrm{hERG}$ protein expression 
A
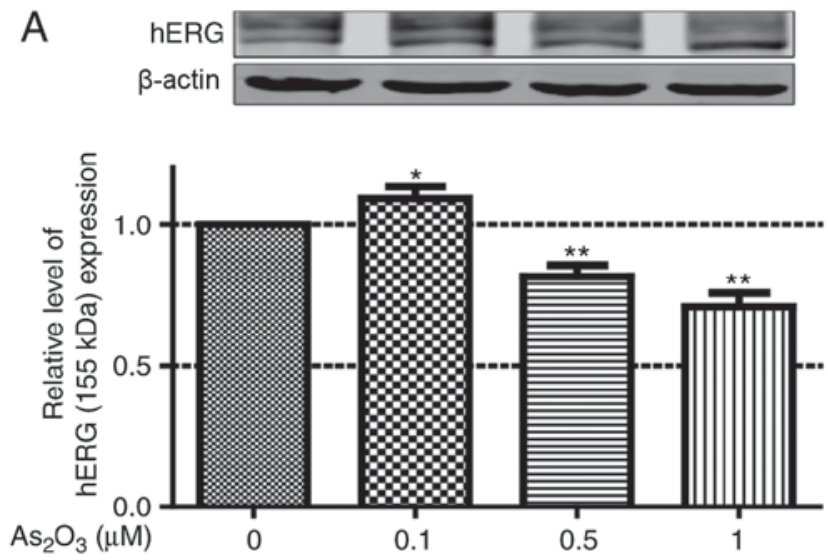

B

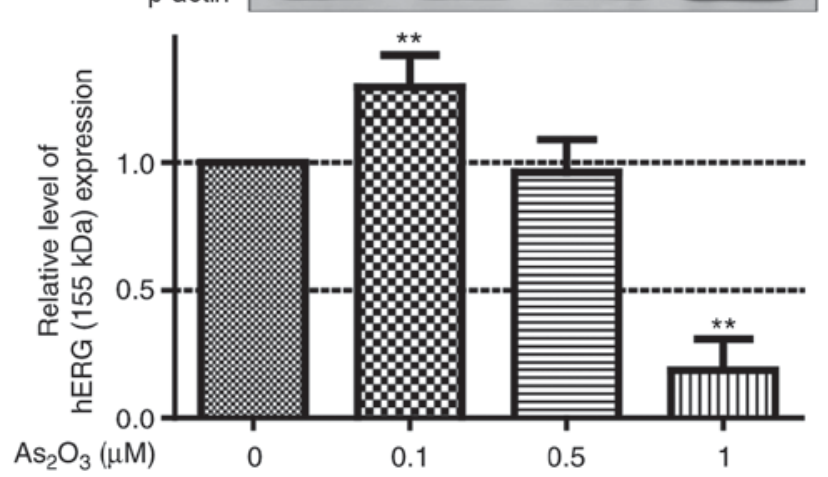

Figure 2. Western blot analysis and quantification of protein expression. (A) Relative expression levels of hERG protein in hERG-293 cells with 0, 0.1, 1 and $10 \mu \mathrm{M} \mathrm{As}_{2} \mathrm{O}_{3}$ treatment. (B) Relative expression levels of hERG protein in MCF-7 cells with $0,0.1,1$ and $10 \mu \mathrm{M}$ As $\mathrm{O}_{3}$ treatment. Data are presented as the mean \pm standard error of the mean $(n=3)$. ${ }^{*} \mathrm{P}<0.05$ or ${ }^{* *} \mathrm{P}<0.01$ vs. control group. $\mathrm{As}_{2} \mathrm{O}_{3}$, arsenic trioxide; hERG, human ether-a-go-go related gene.
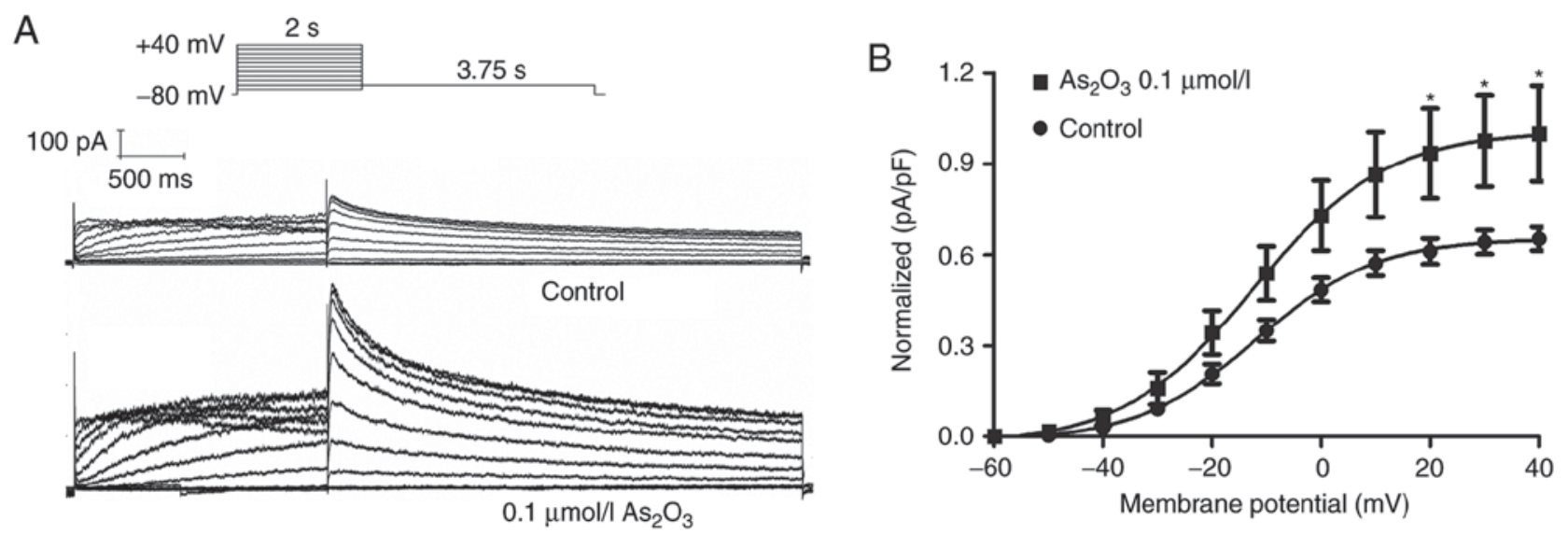

Figure 3. Effect of low-dose $\mathrm{As}_{2} \mathrm{O}_{3}$ on hERG tail current. (A) Voltage-clamp protocol and representative hERG current traces recorded from a hERG-293 cell incubated with $\mathrm{As}_{2} \mathrm{O}_{3}$ for $24 \mathrm{~h}$. (B) Statistical analysis of hERG tail currents. Data are presented as the mean \pm standard error of the mean ( $\mathrm{n}=6$ ). ${ }^{*} \mathrm{P}<0.05$ vs. control. $\mathrm{As}_{2} \mathrm{O}_{3}$, arsenic trioxide; hERG, human ether-a-go-go related gene; VC, voltage-clamp, pa/pf, picoamperes per picofarad.

level in hERG-293 cells was examined. Doses of 0.5 and $1 \mu \mathrm{M} \mathrm{As}_{2} \mathrm{O}_{3}$ significantly reduced hERG protein expression. By contrast, $0.1 \mu \mathrm{M} \mathrm{As}_{2} \mathrm{O}_{3}$ increased hERG protein expression (Fig. 2A). Subsequently, the endogenous hERG levels were also determined in MCF-7 cells, as well as following treatment with $0.1,1$ and $10 \mu \mathrm{M} \mathrm{As}{ }_{2} \mathrm{O}_{3}$ for $24 \mathrm{~h}$ (Fig. 2B). The protein expression level of hERG in the $0.1 \mu \mathrm{M} \mathrm{As}_{2} \mathrm{O}_{3}$ group increased by $35.17 \%$ compared with the control group.

Low-dose $\mathrm{As}_{2} \mathrm{O}_{3}$ enhances the expression of functional hERG channels. Since the transport speed of ions through the membrane depends on the number of functional ion channel proteins, it is necessary to detect the current $\left(\mathrm{I}_{\mathrm{kr}}\right.$ or $\left.\mathrm{I}_{\mathrm{hERG}}\right)$ to verify whether $0.1 \mu \mathrm{M} \mathrm{As} \mathrm{O}_{3}$ could enhance the expression of functional hERG channels. Patch clamp recordings were conducted to detect the effect of $0.1 \mu \mathrm{M} \mathrm{As}_{2} \mathrm{O}_{3}$ on hERG-293 cells after $24 \mathrm{~h}$ of incubation. $\mathrm{I}_{\mathrm{hERG}}$ was elicited during 2 -sec depolarizations (ranging from -60 to $+40 \mathrm{mV}$ ) from a holding potential of $-80 \mathrm{mV}$, then a repolarization to $-50 \mathrm{mV}$ was used to elicit the tail current (Fig. 3A). It was demonstrated that $0.1 \mu \mathrm{M} \mathrm{As} \mathrm{O}_{3}$ enhanced the hERG tail current amplitude by $53.14 \%$ (Fig. 3B). These results suggest that $0.1 \mu \mathrm{M} \mathrm{As}_{2} \mathrm{O}_{3}$ significantly upregulated the expression of functional hERG channels.

Low-dose $\mathrm{As}_{2} \mathrm{O}_{3}$ accelerates hERG channel activation. The properties and/or kinetics of potassium channels are often altered by drugs. Therefore, the activation, steady-state inactivation, and the time courses of the hERG channel were determined in the control and the $\mathrm{As}_{2} \mathrm{O}_{3}$-treated groups. The transient effect of $0.1 \mu \mathrm{M} \mathrm{As} \mathrm{O}_{3}$ on the hERG current was measured. To investigate the effect of low-dose $\mathrm{As}_{2} \mathrm{O}_{3}(0.1 \mu \mathrm{M})$ on hERG potassium channels, patch-clamp experiments were performed on 293 cells stably expressing the wild-type hERG gene. The current-voltage (I-V) association is indicated in Fig. 4. Whole-cell current was first recorded under control conditions, then $0.1 \mu \mathrm{M} \mathrm{As}_{2} \mathrm{O}_{3}$ was added through perfusion equipment at $1.5 \mathrm{ml} / \mathrm{min}$ for $5 \mathrm{~min}$ prior to the next recording. In the presence of $0.1 \mu \mathrm{M} \mathrm{As}_{2} \mathrm{O}_{3}$, the hERG current was notably increased and could be subsequently reversed subsequent to washing out $\mathrm{As}_{2} \mathrm{O}_{3}$. The activation current and tail current reached peak amplitudes at 10 and $20 \mathrm{mV}$, respectively. The ratio of enhancement was calculated using the activation current from 0 to $20 \mathrm{mV}$ and tail current from 0 to $40 \mathrm{mV}$ with 
A
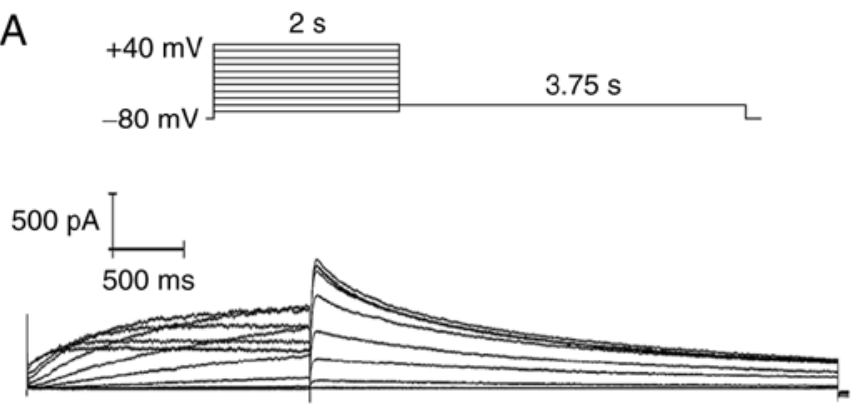

Control

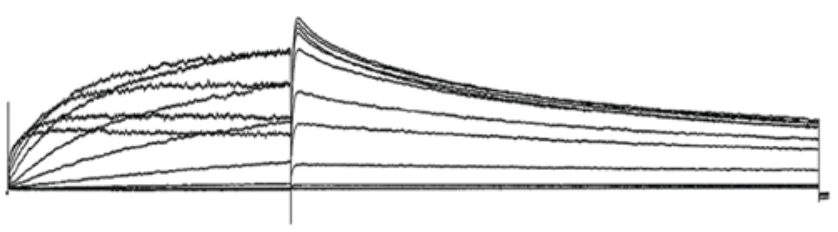

$0.1 \mu \mathrm{mol} / / \mathrm{As}_{2} \mathrm{O}_{3}$

D
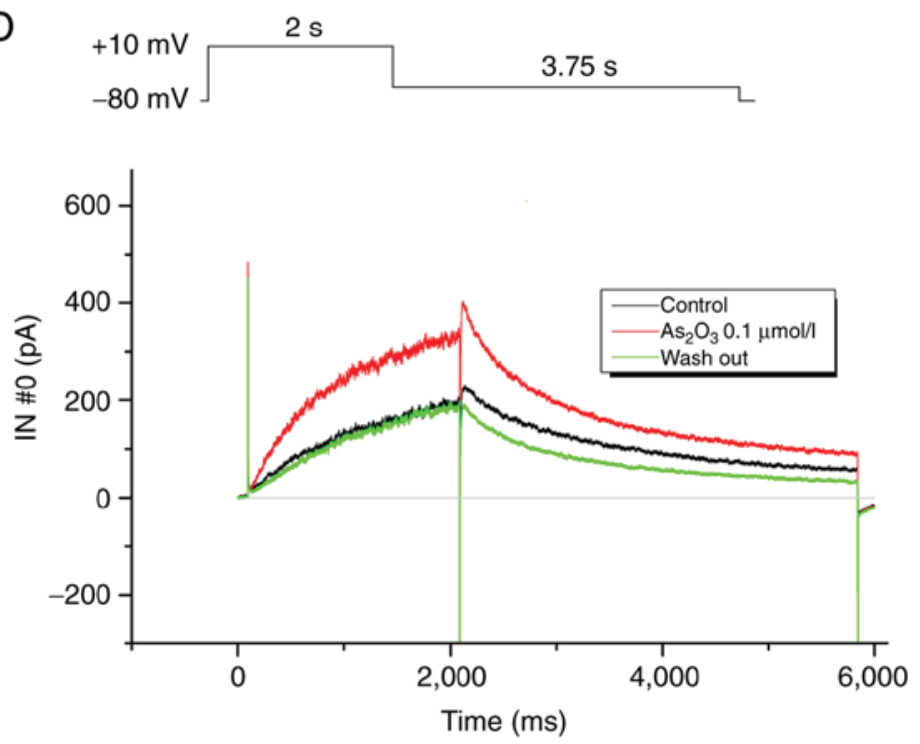

B
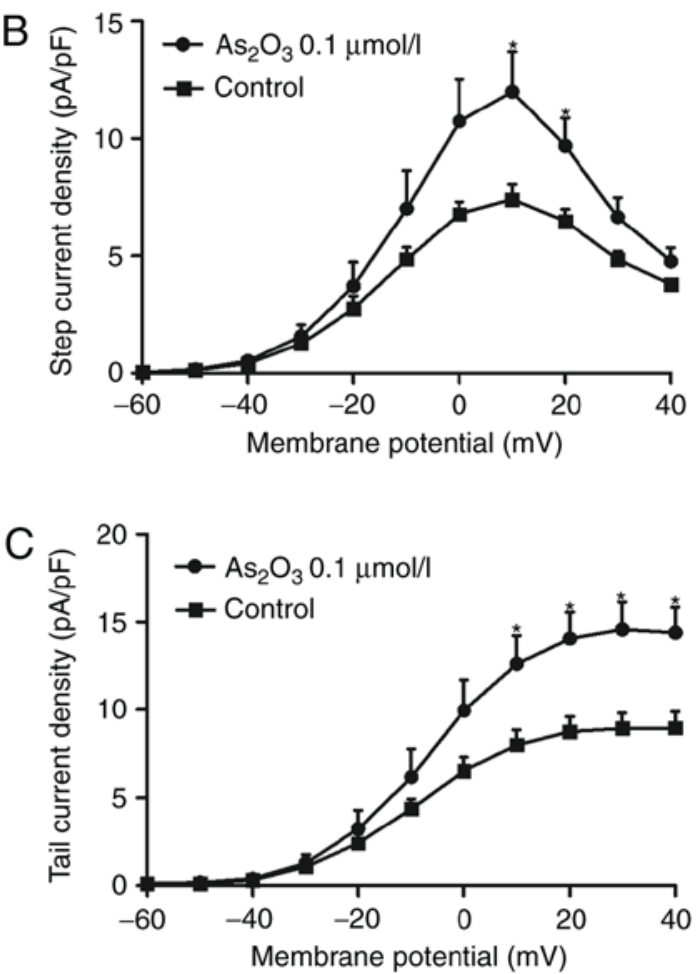

E

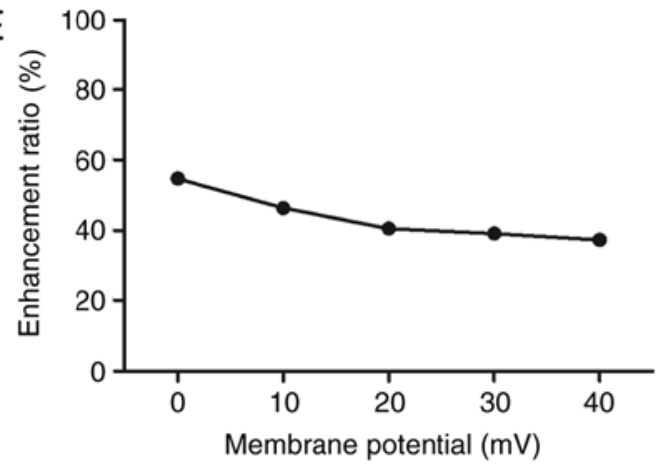

Figure 4. Current-voltage association of hERG channels in the control and $\mathrm{As}_{2} \mathrm{O}_{3}$-treated groups. (A) Voltage-clamp protocol and representative hERG current traces recorded from a hERG-293 cell under low-dose $\mathrm{As}_{2} \mathrm{O}_{3}$ acute perfusion. (B) Current density of hERG channels. (C) Statistical analysis of hERG tail current. (D) Representative hERG current traces recorded from a hERG-293 cell under low-dose $\mathrm{As}_{2} \mathrm{O}_{3}$ acute perfusion and subsequent wash out. (E) Enhancement ratio of hERG current under different membrane potentials. Data are presented as the mean \pm standard error of the mean ( $\mathrm{n}=6$ ). ${ }^{*} \mathrm{P}<0.05$ vs. control group. $\mathrm{As}_{2} \mathrm{O}_{3}$, arsenic trioxide; $\mathrm{VC}$, voltage-clamp; hERG, human ether-a-go-go related gene; pa/pf, picoamperes per picofarad; I-V, current-voltage; IN\#0, channel 0 of Axopatch 200B Amplifier.

the function: $\left(\mathrm{I}_{\mathrm{ato}}-\mathrm{I}_{\mathrm{ctt}}\right) / \mathrm{I}_{\mathrm{ctl}}$. These electrophysiological results suggested that $0.1 \mu \mathrm{M} \mathrm{As}_{2} \mathrm{O}_{3}$ had a significant effect $(\mathrm{P}<0.05)$ on the activation of hERG channels.

Low-dose $\mathrm{As}_{2} \mathrm{O}_{3}$ treatment affects hERG channel kinetics. In a previous study, it was reported that various drugs can influence ion channels by altering the voltage dependence or kinetics of channel gating (19). To investigate the underlying mechanism of the enhanced hERG currents induced by low dose $\mathrm{As}_{2} \mathrm{O}_{3}$ with transient administration, its effects on the voltage dependence of activation and inactivation were examined (Fig. 5). To obtain the half maximal voltage, a Boltzmann function was fitted to the data. The results indicated that $\mathrm{As}_{2} \mathrm{O}_{3}$ shifted the half maximal activation voltage of hERG channels slightly towards negative potentials, from $-4.95 \pm 0.26 \mathrm{mV}$ (in the control group) to $-7.50 \pm 0.25 \mathrm{mV}$ (Fig. $5 \mathrm{~A}$ ) and half maximal inactivation voltage to more positive potentials, from $-94.64 \pm 5.25 \mathrm{mV}$ (in the control group) to $-65.58 \pm 1.71 \mathrm{mV}$ (Fig. 5C). The time interval of onset of inactivation was investigated by fitting a single exponential function to current traces in the third pulse of the protocol (Fig. 6A). The statistical data (Fig. 6B) indicated that inactivation was slower in the presence of $\mathrm{As}_{2} \mathrm{O}_{3}$. The result indicated that low-dose $\mathrm{As}_{2} \mathrm{O}_{3}$ significantly altered the hERG channel kinetics by decreasing the time period of recovery from inactivation (Fig. 6C).

\section{Discussion}

$\mathrm{As}_{2} \mathrm{O}_{3}$ is a popular therapeutic agent for various types of cancer and has been demonstrated to have a high therapeutic 

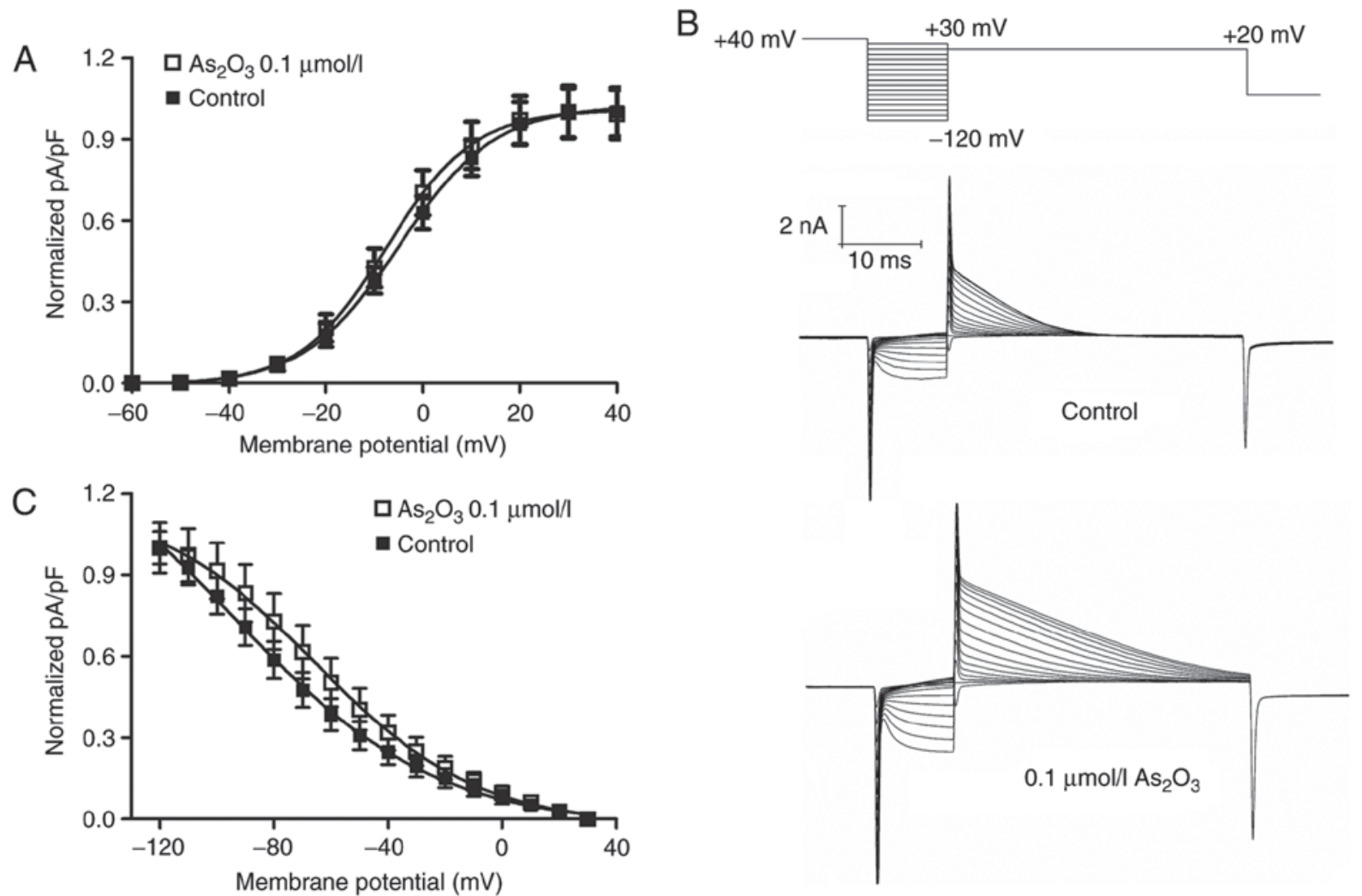

Figure 5. Effects of low dose $\mathrm{As}_{2} \mathrm{O}_{3}$ on voltage-dependent activation curves and inactivation curves of hERG channels. (A) Voltage-dependent activation curves for the control and following exposure to low-dose $\mathrm{As}_{2} \mathrm{O}_{3}$ for $24 \mathrm{~h}$. (B) Voltage-clamp protocol and representative current tracing for steady-state inactivation. (C) Inactivation curve of hERG channels after treatment with low-dose $\mathrm{As}_{2} \mathrm{O}_{3}$ for $24 \mathrm{~h}$. Data are presented as the mean \pm standard error of the mean ( $\mathrm{n}=6$ ). $\mathrm{As}_{2} \mathrm{O}_{3}$, arsenic trioxide; hERG, human ether-a-go-go related gene; VC, voltage-clamp; pa/pf, picoamperes per picofarad.

effect in APL. However, the adverse effects of arsenic trioxide, including cardiotoxicity and carcinogenicity, remain a clinical problem (20). The adverse effects of chronic arsenic toxicity in humans are referred to as arsenicosis $(21,22)$. Although researchers have reported significant associations between the occurrence of tumors and arsenicosis, the underlying mechanism remains unclear.

The most common oxidation states of arsenic include arsenite and arsenate (23). Among these, $\mathrm{As}_{2} \mathrm{O}_{3}$ is the most prevalent inorganic arsenical found in the air or in underground water $\left(\mathrm{AsO}_{2}^{-}\right)(24)$. Therefore, the present study was mainly based on $\mathrm{As}_{2} \mathrm{O}_{3}$ and not arsenate. In our previous studies, $\mathrm{As}_{2} \mathrm{O}_{3}$ was demonstrated to regulate the expression of hERG channels (18). In addition, it has been demonstrated that the proliferation-facilitating effect of $\mathrm{As}_{2} \mathrm{O}_{3}$ is significantly more pronounced in hERG-expressing cells than in hERG-lacking tumor cells (25), which indicates that hERG channels serve an important role in the regulation of tumor progression. Accordingly, we hypothesized that hERG channels may be involved in the process of arsenicosis. To investigate this, viability and apoptotic rate was compared in response to $\mathrm{As}_{2} \mathrm{O}_{3}$ stimulation in MCF-7 and A549 cells. The results indicate that a medium or high dose of $\mathrm{As}_{2} \mathrm{O}_{3}$ inhibited proliferation and promoted apoptosis. However, a low dose of $\mathrm{As}_{2} \mathrm{O}_{3}$ treatment simultaneously promoted proliferation and increased apoptosis in MCF-7 cells compared with control group. This hormesis phenomenon is similar to that of the tumor necrosis factor
(TNF) superfamily. TNF has been demonstrated to be an endogenous cancer promoter that stimulates cancer cell invasion and proliferation $(22,23)$, but by contrast, TNF has also been proven to be an endogenous cancer killer (26). This hormesis phenomenon was not observed in A549 cells. This suggests that MCF-7 cells were more sensitive than A549 cells to $\mathrm{As}_{2} \mathrm{O}_{3}$.

The hormesis of $\mathrm{As}_{2} \mathrm{O}_{3}$ has also been demonstrated by other research groups $(10,25)$. It was reported that a low dose of $\mathrm{As}_{2} \mathrm{O}_{3}$ could stimulate osteoblast and MTLn3 cell proliferation (10). Wang et al (27) demonstrated that hERG protein expression is associated with tumor-cell proliferation and cancer development. To address whether hERG channels were involved in this process, 293 cells overexpressing hERG channels were used in the present study. hERG current and electrophysiological characteristics are relatively easy to detect in this cell model (28-30). hERG-293 cells were incubated with $0.1,0.5$ and $1 \mu \mathrm{M} \mathrm{As}_{2} \mathrm{O}_{3}$ for $24 \mathrm{~h}$. The results demonstrated that $0.1 \mu \mathrm{M} \mathrm{As} \mathrm{O}_{2} \mathrm{O}_{3}$ was able to increase the expression of hERG channels compared with the control group. In addition, $0.1 \mu \mathrm{M}$ $\mathrm{As}_{2} \mathrm{O}_{3}$ increased endogenous hERG expression in MCF-7 cells. This is notable since it was previously accepted that $\mathrm{As}_{2} \mathrm{O}_{3}$ was a hERG channel inhibitor. This is the first study, to the best of our knowledge, to demonstrate that a low dose of $\mathrm{As}_{2} \mathrm{O}_{3}$ could exert an inverse effect compared with high-dose administration.

To verify the results, the influence of a low dose of $\mathrm{As}_{2} \mathrm{O}_{3}$ on hERG current and channel kinetics was analysed. The 
A
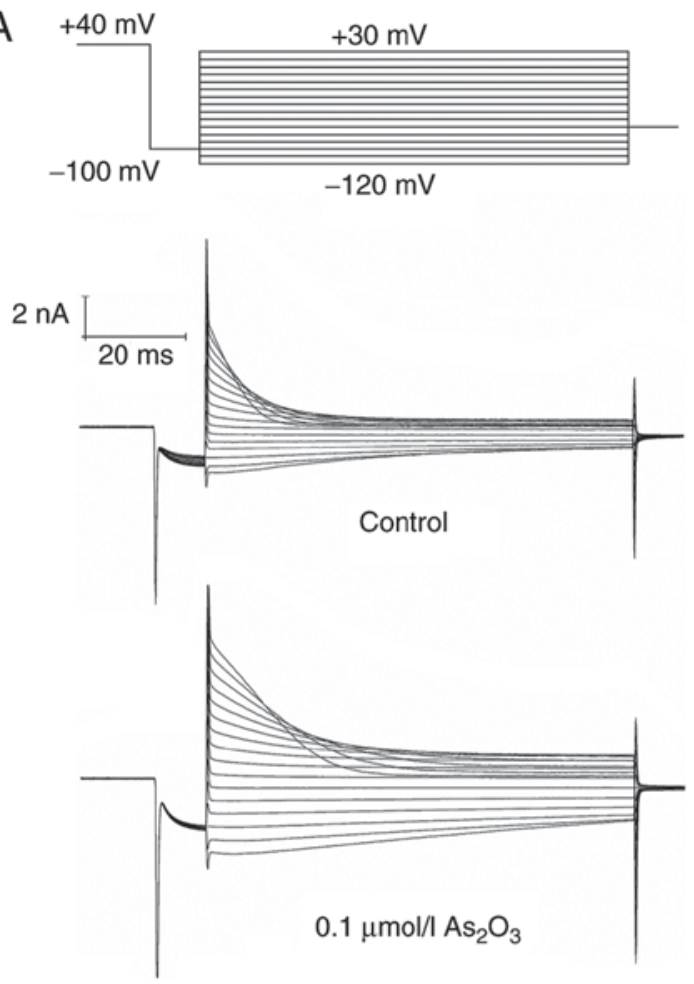

B

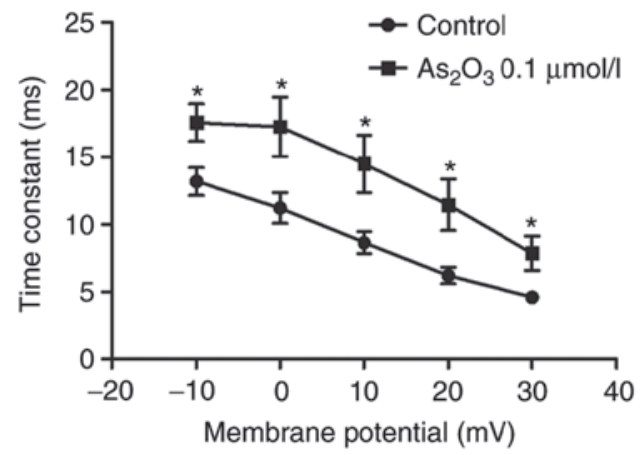

C
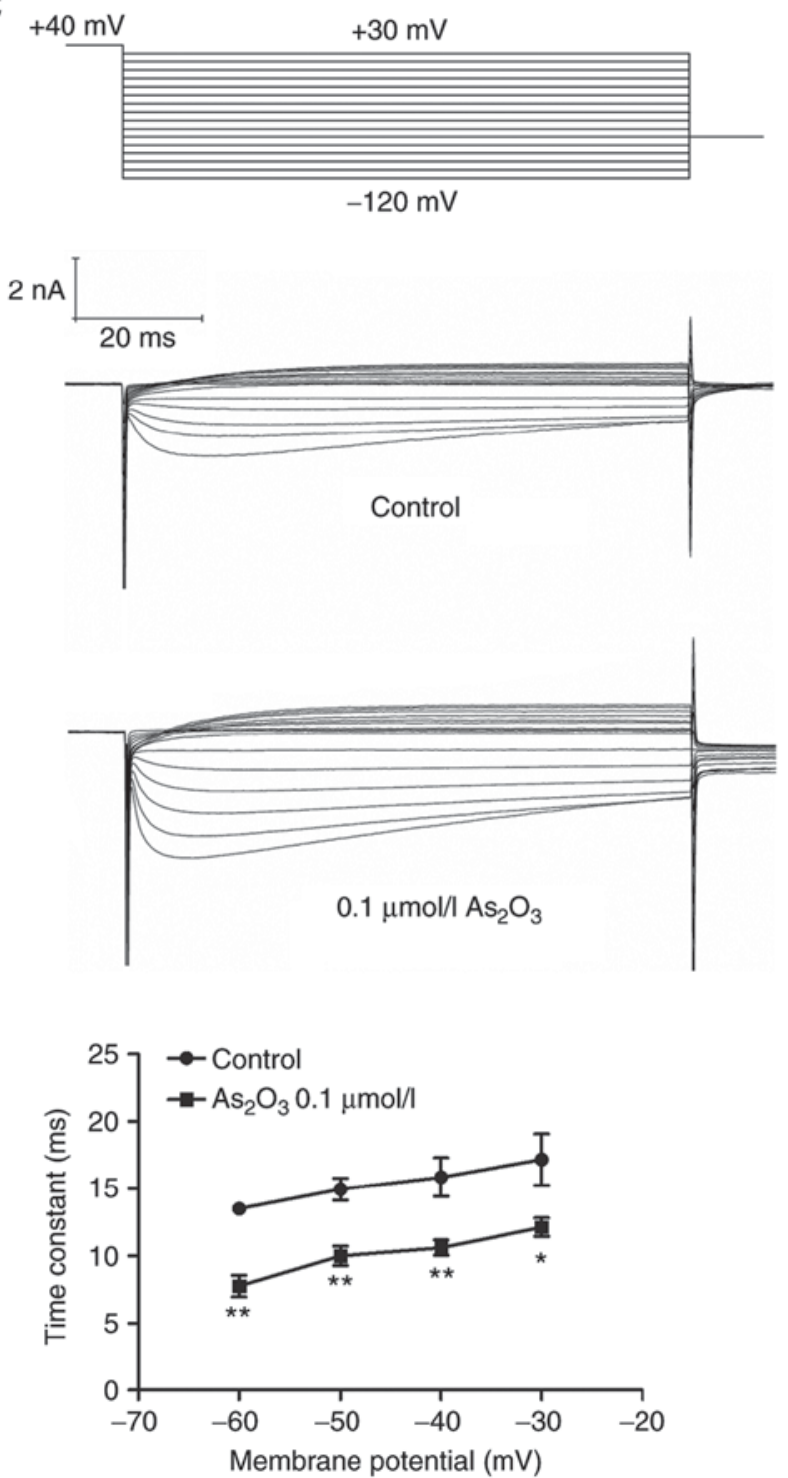

Figure 6. Effects on voltage dependence of activation and inactivation. (A) Voltage-clamp protocol and representative current tracing for the onset of inactivation. (B) Effect of low-dose $\mathrm{As}_{2} \mathrm{O}_{3}$ on the time period of onset of inactivation following treatment for $24 \mathrm{~h}$. (C) Voltage-clamp protocol and representative current tracing for recovery from inactivation. (D) Effect of low-dose $\mathrm{As}_{2} \mathrm{O}_{3}$ on the recovery from inactivation following treatment for $24 \mathrm{~h}$. Data are presented as the mean \pm standard error of the mean $(n=6)$. ${ }^{*} \mathrm{P}<0.05$ or ${ }^{* *} \mathrm{P}<0.01$ vs. control group. $\mathrm{As}_{2} \mathrm{O}_{3}$, arsenic trioxide; VC, voltage-clamp.

results indicated that a low dose of $\mathrm{As}_{2} \mathrm{O}_{3}$ not only increased the hERG current, but also accelerated hERG channel activation. In addition, low-dose $\mathrm{As}_{2} \mathrm{O}_{3}$ treatment markedly affected hERG channel kinetics by causing a slower rate of channel inactivation and faster recovery time, compared with the untreated cells.

The hERG channel has previously been demonstrated to positively regulate tumor proliferation (31). The data of the present study revealed that a low dose of $\mathrm{As}_{2} \mathrm{O}_{3}$ promoted hERG protein expression and provided a plausible explanation for arsenicosis-induced tumorigenesis. However, the present study did not investigate the involvement of any other molecules or signaling pathways, which could affect this process. Therefore, further research is required.

It should be noted that the research of the present study also has certain limitations. Due to the specificity of tumor cells and limitations in experimental techniques, particularly the patch-clamp technique, tracking and recording the characteristics of ion channels on tumor cells was not possible. Therefore, hERG-293 cells were used as a mature cell model for the investigation of electrophysiological characteristics of hERG potassium channels, as previously described $(18,32)$.

In summary, the present study provides evidence that a low dose of $\mathrm{As}_{2} \mathrm{O}_{3}$ promotes tumorigenesis through upregulating hERG channel expression and affecting hERG channel kinetics. Although $\mathrm{As}_{2} \mathrm{O}_{3}$ was previously demonstrated to be an hERG channel inhibitor, it was demonstrated that a low dose of $\mathrm{As}_{2} \mathrm{O}_{3}$ exhibits the opposite effect, promoting hERG channel expression and enhancing hERG current. These findings may help to identify therapeutic strategies for patients with arsenicosis, and provide a novel understanding of the association between $\mathrm{As}_{2} \mathrm{O}_{3}$ and hERG channels. 


\section{Acknowledgements}

The authors would like to thank Dr Yuanqi Shi (Department of Cardiology, The First Affiliated Hospital of Harbin Medical University, Harbin, China) for providing assistance with the patch-clamp technology.

\section{Funding}

This study was supported by grants from the Major Program of the National Natural Science Foundation of Heilongjiang (grant no. ZD 2015015), and the National Natural Science Foundation of China (grant nos. 81673636 and 81173050).

\section{Availability of data and materials}

The datasets used and/or analyzed during the current study are available from the corresponding author on reasonable request.

\section{Authors' contributions}

$\mathrm{XZ}$ is responsible for the writing and design of the manuscript. DY is responsible for performance of the western blot assay. HG is responsible for performance of the western blot assay. FL is responsible for performance of the Patch clamp. LL is responsible for performance of Flow Cytometry. LZ is responsible for performance of the Patch clamp. CY is responsible for the design of the subject and writing of the manuscript. BL is the provider of the funding and is responsible for the study design.

\section{Ethics approval and consent to participate}

There is no clinical, patient, tissue or animal experimentation involved in the present study.

\section{Patient consent for publication}

Not applicable.

\section{Competing interests}

The authors declare that they have no competing interests.

\section{References}

1. Curran ME, Splawski I, Timothy KW, Vincent GM, Green ED and Keating MT: A molecular basis for cardiac arrhythmia: HERG mutations cause long QT syndrome. Cell 80: 795-803, 1995.

2. Haverkamp W, Breithardt G, Camm AJ, Janse MJ, Rosen MR, Antzelevitch C, Escande D, Franz M, Malik M, Moss A and Shah R: The potential for QT prolongation and proarrhythmia by non-antiarrhythmic drugs: Clinical and regulatory implications. Report on a policy conference of the European Society of Cardiology. Eur Heart J 21: 1216-1231, 2000.

3. Farkas AS and Nattel S: Minimizing repolarization-related proarrhythmic risk in drug development and clinical practice. Drugs 70: 573-603, 2010.

4. Kannankeril P, Roden DM and Darbar D: Drug-induced long QT syndrome. Pharmacol Rev 62: 760-781, 2010.

5. Bi LL, Ma Q and Wang SQ: Treatment of 32 cases with recurring acute promyelocytic leukemia with tablets of composite natural indigo. Zhonghua Er Ke Za Zhi 43: 702-703, 2005 (In Chinese).
6. Chen GQ, Shi XG, Tang W, Xiong SM, Zhu J, Cai X, Han ZG, $\mathrm{Ni}$ JH, Shi GY, Jia PM, et al: Use of arsenic trioxide (As2O3) in the treatment of acute promyelocytic leukemia (APL): I. As2O3 exerts dose-dependent dual effects on APL cells. Blood 89: 3345-3353, 1997.

7. Zhang TC, Cao EH, Li JF, Ma W and Qin JF: Induction of apoptosis and inhibition of human gastric cancer MGC-803 cell growth by arsenic trioxide. Eur J Cancer 35: 1258-1263, 1999.

8. Ye J, Li A, Liu Q, Wang X and Zhou J: Inhibition of mitogenactivated protein kinase kinase enhances apoptosis induced by arsenic trioxide in human breast cancer MCF-7 cells. Clin Exp Pharmacol Physiol 32: 1042-1048, 2005.

9. Wang C, Chen X, Wu J, Liu H, Ji Z, Shi H, Gao C, Han D, Wang L, Liu Y, et al: Low-dose arsenic trioxide enhances 5-aminolevulinic acid-induced PpIX accumulation and efficacy of photodynamic therapy in human glioma. J Photochem Photobiol B 127: 61-67, 2013.

10. Raja WK, Satti J, Liu G and Castracane J: Dose response of MTLn3 cells to serial dilutions of arsenic trioxide and ionizing radiation. Dose Response 11: 29-40, 2013.

11. Ganapathy S, Li P, Fagman J, Yu T, Lafontant J, Zhang G and Chen C: Low doses of arsenic, via perturbing p53, promotes tumorigenesis. Toxicol Appl Pharmacol 306: 98-104, 2016.

12. Becchetti A, Crescioli S, Zanieri F, Petroni G, Mercatelli R, Coppola S, Gasparoli L, D'Amico M, Pillozzi S, Crociani O, et al: The conformational state of hERG1 channels determines integrin association, downstream signaling, and cancer progression. Sci Signal 10: pii: eaaf3236, 2017.

13. Crociani O, Lastraioli E, Boni L, Pillozzi S, Romoli MR, D'Amico M, Stefanini M, Crescioli S, Masi A, Taddei A, et al: hERG1 channels regulate VEGF-A secretion in human gastric cancer: Clinicopathological correlations and therapeutical implications. Clin Cancer Res 20: 1502-1512, 2014.

14. Fortunato A: The role of hERG1 ion channels in epithelial-mesenchymal transition and the capacity of riluzole to reduce cisplatin resistance in colorectal cancer cells. Cell Oncol (Dordr) 40: 367-378, 2017.

15. Ficker E, Kuryshev YA, Dennis AT, Obejero-Paz C, Wang L, Hawryluk P, Wible BA and Brown AM: Mechanisms of arsenic-induced prolongation of cardiac repolarization. Mol Pharmacol 66: 33-44, 2004.

16. Wan X, Dennis AT, Obejero-Paz C, Overholt JL, Heredia-Moya J, Kirk KL and Ficker E: Oxidative inactivation of the lipid phosphatase phosphatase and tensin homolog on chromosome ten (PTEN) as a novel mechanism of acquired long QT syndrome. J Biol Chem 286: 2843-2852, 2011.

17. Chen SZ, Jiang $M$ and Zhen YS: Correlation of HERG K+ channel protein expression to chemosensitivity of tumor cells to doxorubicin and its modulation by erythromycin. Ai Zheng 24: 924-929, 2005 (In Chinese).

18. Zhang Y, Dong Z, Jin L, Zhang K, Zhao X, Fu J, Gong Y, Sun M, Yang B and Li B: Arsenic trioxide-induced hERG K(+) channel deficiency can be rescued by matrine and oxymatrine through up-regulating transcription factor Sp1 expression. Biochem Pharmacol 85: 59-68, 2013.

19. Nicholson GM, Blanche T, Mansfield K and Tran Y: Differential blockade of neuronal voltage-gated $\mathrm{Na}(+)$ and $\mathrm{K}(+)$ channels by antidepressant drugs. Eur J Pharmacol 452: 35-48, 2002.

20. Pace C, Dagda R and Angermann J: Antioxidants protect against arsenic induced mitochondrial Cardio-toxicity. Toxics 5: pii: E38, 2017.

21. Sarkar A and Paul B: The global menace of arsenic and its conventional remediation-A critical review. Chemosphere 158: 37-49, 2016.

22. Oremland RS and Stolz JF: Arsenic, microbes and contaminated aquifers. Trends Microbiol 13: 45-49, 2005.

23. Orloff K, Mistry K and Metcalf S: Biomonitoring for environmental exposures to arsenic. J Toxicol Environ Health B Crit Rev 12: 509-524, 2009.

24. Reeve BB, Burke LB, Chiang YP, Clauser SB, Colpe LJ, Elias JW, Fleishman J, Hohmann AA, Johnson-Taylor WL, Lawrence W, et al: Enhancing measurement in health outcomes research supported by Agencies within the US Department of Health and Human Services. Qual Life Res 16 (Suppl 1): S175-S186, 2007.

25. Xu WX, Liu Y, Liu SZ, Zhang Y, Qiao GF and Yan J: Arsenic trioxide exerts a double effect on osteoblast growth in vitro. Environ Toxicol Pharmacol 38: 412-419, 2014.

26. Lin $\mathrm{X}$, Chen Q, Huang $\mathrm{C}$ and $\mathrm{Xu} \mathrm{X}$ : CYLD promotes TNF- $\alpha$-induced cell necrosis mediated by RIP-1 in human lung cancer cells. Mediators Inflamm 2016: 1542786, 2016. 
27. Wang H, Zhang Y, Cao L, Han H, Wang J, Yang B, Nattel S and Wang Z: HERG K+ channel, a regulator of tumor cell apoptosis and proliferation. Cancer Res 62: 4843-4848, 2002.

28. Li P, Ninomiya H, Kurata Y, Kato M, Miake J, Yamamoto Y, Igawa O, Nakai A, Higaki K, Toyoda F, et al: Reciprocal control of hERG stability by Hsp70 and Hsc70 with implication for restoration of LQT2 mutant stability. Circ Res 108: 458-468, 2011.

29. Dong ZX, Zhao X, Gu DF, Shi YQ, Zhang J, Hu XX, Hu MQ, Yang BF and Li BX: Comparative effects of liensinine and neferine on the human ether-a-go-go-related gene potassium channel and pharmacological activity analysis. Cell Physiol Biochem 29: 431-442, 2012.

30. Yang Z, Prinsen JK, Bersell KR, Shen W, Yermalitskaya L, Sidorova T, Luis PB, Hall L, Zhang W, Du L, et al: Azithromycin causes a novel proarrhythmic syndrome. Circ Arrhythm Electrophysiol 10: pii: e003560, 2017.
31. Staudacher I, Jehle J, Staudacher K, Pledl HW, Lemke D, Schweizer PA, Becker R, Katus HA and Thomas D: HERG K+ channel-dependent apoptosis and cell cycle arrest in human glioblastoma cells. PLoS One 9: e88164, 2014.

32. Shi YQ, Yan M, Liu LR, Zhang X, Wang X, Geng HZ, Zhao X and Li BX: High glucose represses hERG K+ channel expression through trafficking inhibition. Cell Physiol Biochem 37: 284-296, 2015.

cc) (i) $\ominus$ This work is licensed under a Creative Commons Attribution-NonCommercial-NoDerivatives 4.0 International (CC BY-NC-ND 4.0) License. 